\title{
Impact of Semi-Autonomous Revenue Authority on Tax Revenue and Buoyancy: Evidence from Pakistan
}

\author{
Imtiaz Arif * $\quad$ Lubna Khan ${ }^{\dagger} \quad$ Faheem Hussain ${ }^{\ddagger}$
}

\begin{abstract}
This paper efforts to investigate the effect of semi-autonomous revenue authority (SARA) on the tax revenue and tax buoyancy of Pakistan. The current study uses the annual time series data spanning the period between 1972-2015 was used. After ensuring the stationary property of the data series and long-run relationship between variables, the regression analysis is employed to test the model. The results reveal that gross domestic product substantially increases the tax revenue collection. Moreover, the impact of SARA reforms is insignificant but positive in Pakistan. However, the cumulative effect of SARA reforms and real income becomes negative and insignificant on the tax revenue productivity. So study proposes some useful implication for the policy makers about the improvement of tax revenue productivity.
\end{abstract}

Keywords: Semi-autonomous revenue authority, tax revenue, tax buoyancy, gross domestic product, Pakistan.

\section{Introduction}

External as well as internal pressure on the developing nations, about the mobilization of tax revenue has grown recently. Tax revenue plays a central role in the economic growth and has remained an essential source of income for most of the world economies. Due to the fiscal imbalances, governments endeavor to design policies and tax reforms which can efficiently contribute to the increase in tax revenue. Di John (2011) highlighted that tax revenue collection and reforms are inevitable for several reasons; first and the foremost is to maximise fund generation for the development and economic growth. Second, taxation enhances the government accountability; third, it strengthens the capability of the government and fourth, tax reforms improve the governance of the country. However, most of the developing economies have remained unsuccessful to comply such policies and reforms due to weak governance, prone to corruption and political interventions.

To deal with the efficiency in the tax revenue collection and effective implementation of tax policies, governments have introduced the innovative design of an institution called a semi-autonomous revenue agency (SARA). SARA is an administrative body with independent legal status and a decentralized institution inspired by new management approaches, strategic management and effective regulatory policies. This reform stresses the impor-

\footnotetext{
*Asst. Professor, Iqra University. E-mail: arif.i@iuk.edu.pk

${ }^{\dagger}$ Research Associate, Iqra University. E-mail: lubna_khan92@hotmail.com

${ }^{\ddagger}$ Post Graduate Student.
} 
tance of taxpayers, accountability, transparency and good governance (Levi \& Sacks, 2009; Eubank, 2012). Internationally SARA has received its recognition as one of the most effective tax reform relative to the conventional tax policies (Tax Administration in OECD and Selected Non-OECD Countries, 2011). Contrary to the conventional taxation, SARA enjoys a certain level of autonomy in their financial and operational functions about budget allocation, payments, staffing, and other internal services of the organization. According to the reports, semi-autonomous revenue agency exists in 50 countries of the world. It is also deliberated that SARA is the most effective tool to deal with the revenue collection, political intervention, and corruption.

Over the period Pakistan is continuously facing fiscal deficit. The uncertainty in economic policy and political situations are the critical factors which are contributing to such position. In the 1970s, the budget deficit was 6 per cent of GDP and increased by 7.6 per cent in 1980s. However, by reducing the developmental expenditures, the budget deficit was decreased by 6.4 per cent. In 2000, Pakistan introduced some prudent reforms to increase their tax revenue productivity. As a consequence, the tax revenue as a percentage of GDP was increased by 13.3 per cent in 2001 and 14.2 per cent in 2002. Due to the progressive tax reforms, Pakistan fiscal deficit decreased by 5.2 per cent. In 2007, the state initiated an effective tax reform by redesigning the central board of revenue (CBR) as a semi-autonomous revenue authority named as federal board revenue (FBR). Despite the compelling characteristics of SARA, countries have failed to execute such policies as per their expectations. Few past studies have raised concerned about the performance of SARA particularly in developing countries (Kidd \& Crandall, 2006; Taliercio Jr, 2004; Di John, 2011). Empirical analysis of different countries where SARA was implemented show mixed results. In Peru and Ghana implementation of SARA improved tax revenue collection, while no impact found in Malaysia and Venezuela. However, in Tanzania and Rwanda, the actual performance of SARA has reduced the revenue collection.

After establishment of FBR (which is SARA), for the improvement and mobilization of tax revenue, a debate on the effect of SARA on tax revenue has begun. The graph below illustrate the performance of CBR/FBR on the basis of tax-to-GDP ratio during the period of 1972 to 2015. It is easy to conclude that FBR has failed to make any positive impact on tax revenue collection.

However, several past studies have measured the performance of SARA reforms by using tax buoyancy (Omondi, Wawire, Manyasa, \& Thuku, 2014; Upender et al., 2008). They argued, tax buoyancy is an effective indicator that measure the change in tax revenue in response to the change in national income by considering the change in tax policy reforms. Therefore, in this current study, we attempt to investigate the effect of SARA reforms (which is FBR) on the tax revenue and tax buoyancy of Pakistan. This research is useful to gauge the performance of SARA, whether it succeeds or fails to improve the tax collection process. 
Figure 1

Tax-to-GDP Ratio: Pakistan (1972-2016)

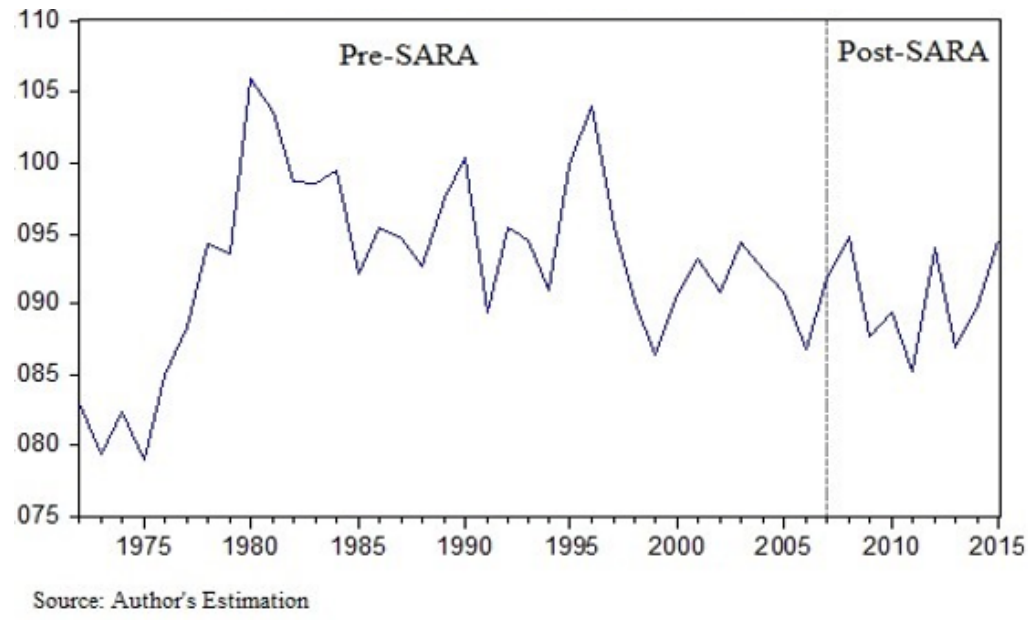

\section{A Semi-autonomous Revenue Agency (SARA):}

A semi-autonomous revenue agency (SARA) enjoys an independent legal status with no involvement of ministries. Unlike conventional institutions, SARA has limited capability regarding formulating and reporting policies to the ministry of finance. Therefore, these institutions are considered different from the conventional ones, containing several advantages (Taliercio Jr, 2004). Moreover, SARA provides a more comprehensive model for the tax system to improve the tax mobilization. Normally, developing states are unable to generate sufficient amount from taxes because of corruption, weak governance and political intervention. Thus, SARA reforms are capable of dealing with the tax volatility (Talvi \& Vegh, 2005).

\section{Pre-SARA Studies}

Several past empirical studies have discussed the relationship between tax revenue, tax buoyancy and tax reforms in their studies. For instance, Musa, Bulus, Nwokolo, and Yuni (2016) examined the relation of tax buoyancy, elasticity and tax revenue in Nigeria. They tried to identify whether tax buoyancy and elasticities measure the change in revenue. By using vector error correction model (VECM), authors identified that tax elasticities and buoyancy have a significant and positive relation with the tax revenue of Nigeria, which means that tax buoyancy measures the change in tax revenue. Authors recommended to the Nigerian government to introduce such policies and take advantage of the essentials of the country, generate another source of financing other than crude oil by raising tax revenues. Similarly, Ahmed and Muhammad (2010) also identified the determinants of tax buoyancy in developing countries. They found that gross domestic product of developing 
countries is highly tax buoyant. The findings also revealed that tax revenue is highly influenced by the budget deficit of the country because it demands the government to mobilize resources. However, the effect of agriculture sector growth has an insignificant impact on the tax buoyancy of developing countries because of the tax exemption. A similar study of Upender et al. (2008) investigated the degree of tax buoyancy in India. The author found an interesting finding that an Indian tax system is buoyant in the pre reform period. However, the system becomes non-buoyant at the time of post reform. Therefore, the government was advised to consider the execution of the tax reforms in the country. Moreover, Kargbo and Egwaikhide (2012) explored the tax system of Sierra Leone. They found that the tax system of the country is not buoyant due to the inconsistent reforms. The state should maintain consistency and effective implementation of the reforms so that it generates revenue.

\section{Post-SARA Studies}

After the establishment of semi-autonomous revenue agencies (SARAs), researchers initiated studies to explore the effects of SARA reforms on the tax system and most importantly on the tax revenue. Numerous studies investigated the effectiveness of SARA reforms and its effects on the tax revenue and the economy as a whole. Von Haldenwang, Von Schiller, and Garcia (2014) examine the performance of SARA on the collection and variation of tax revenue in the developing state of Peru. Researcher find that semi-autonomous revenue agencies have become a crucial element for the reforms of public administrations; it improves the tax revenue mobilization and the robustness in the relationship between taxpayers and states. They noted that in the early two years, when SARA was struggling to maintain an edge over the conventional autonomous body, even than a strong and positive effect was observed. Moreover, it is found that SARA successfully contributes to the tax system by providing stable and predictable tax revenue collection. Likewise, Muriithi and Moyi (2003) evaluated the productivity of tax system in Kenya during the pre and post period of tax reforms. The study found that tax reforms have a strong and positive influence on both the individual and overall tax structure. It is also found that tax reforms in Kenya have a small effect on the indirect taxes relative to the direct taxes indicating a revenue leakage problem. Therefore, it is suggested to the policy makers to design policies that reduce the problem of indirect taxes. In similar with, Bekoe, Danquah, and Senahey (2016) studied the effectiveness of the mobilization of the tax reforms in Ghana. The result revealed that tax system of Ghana during the pre-reform period was not elastic and tax buoyant due to the weak administration. Contrary to the pre reform period results revealed that the tax system of Ghana in the post reform period has become elastic and buoyant.

From the above empirical studies, we can assume a strong positive influence of semiautonomous agencies on the process of tax collection. Earlier studies have noted a significant direct relation between variables. In this current study, we attempt to investigate the effectiveness of SARA reforms, i.e., the federal board of revenue (FBR) on the tax revenue of Pakistan. In this context, there are various external factors such as corruption, political interference, weak governance, etc. that influence the independent body (SARA) and then 
the economy. This study will enable us to determine the FBR performance and will allow us to set future path.

\section{Methodology}

After reviewing the past theoretical and empirical studies, we have identified two models that measure the productivity of tax revenue collection. The first model estimates tax revenue productivity in responsiveness to the change in national income. The model is proposed by Prest (1962), which was further used by Ariyo (1997); Osoro (1993); Gillani (1986) and many others. The proposed model is given below;

$$
\ln T=\alpha_{0}+\beta \ln G D P+\epsilon
$$

Whereas $\ln T$ is the $\log$ of tax collected and $\ln G D P$ is the $\log$ of national income measured by gross domestic product. Also, the second model refereed as dummy variable approach is proposed by Singer (1968). In this approach, dummy variables were adjusted to the above model to measure the effects of tax reforms and tax buoyancy. This model was also used in earlier studies such as Upender et al. (2008); Kargbo and Egwaikhide (2012); Ndedzu, Macheka, Ithiel, and Zivengwa (2013) etc.

Similarly, in this study, we have used the adjusted model of Singer (1968) to measure the effect of tax reforms (SARA) on the tax revenue. Moreover, this model also measures the tax buoyancies of the pre-reform and post-reform periods. The model is given below;

$$
\ln T R_{t}=\alpha_{t}+\beta_{1} \ln G D P+\beta_{2} D U M_{t}+\beta_{3} D_{2}+\epsilon_{t}^{\prime}
$$

Where $\ln T R$ is the log of total tax revenue, defined as the revenue collected from taxes. $\ln G D P$ is the log of gross domestic product, referred as the national income of the country. However, the DUM is the dummy variable covers the pre-SARA period and post-SARA period and $D_{2}$ is the slope dummy variable generated by multiplying dummy variable and gross domestic product $(D U M * \ln G D P)$ to measure the cumulative effect of SARA reforms and economic growth on the tax revenue (i.e. tax buoyancy).

This study uses annual time series data of tax revenue and gross domestic product of Pakistan for the period of 1972 to 2015 . Based on the availability of data, we have selected time period that contain both the pre- SARA and post-SARA periods. From 1972-2006, the years considered as pre-SARA period, whereas, after the establishment of federal board of revenue (FBR), 2007-2015 are considered as the post-SARA period. The entire data of all the variables were collected in a million rupees from the federal board of revenue (FBR) and State Bank of Pakistan (SBP).

For the empirical analysis of the model (equation 2), we use simple linear regression to estimate the effects of tax reforms on the tax revenue of Pakistan in the selected period. Before the estimation, we also check the integration property of the data series using augmented dickey fuller (ADF) test, long-run relationship using JJ cointegration and the causal relationship using granger causality. 


\section{Empirical Findings and Discussion}

\section{Descriptive Statistics}

The result of descriptive statistics of Pre-SARA and Post-SARA periods are presented in table 1. The Pre-SARA period covers 1972-2006 and Post-SARA period covers years from 2007-2015. The average tax revenue in the Pre-SARA period is 198,803 with the standard deviation of 217,668 . Whereas, the average gross domestic product in the same period is $2,099,638$ with the standard deviation $2,406,762$. However, the average tax revenue in the Post-SARA period increased and amounted as 1,715,661 with a standard deviation of 550,728 . Moreover, the average value of GDP in the same period is 18,982,274 with standard deviation 5,865,077.

Table 1

Descriptive Statistics

\begin{tabular}{lcccc}
\hline Statistics & \multicolumn{2}{c}{ Pre- SARA } & \multicolumn{2}{c}{ Post- SARA } \\
\hline & $\begin{array}{c}\text { TR } \\
\text { (in Rupees) }\end{array}$ & $\begin{array}{c}\text { GDP } \\
\text { (in Rupees) }\end{array}$ & $\begin{array}{c}\text { TR } \\
\text { (in Rupees) }\end{array}$ & $\begin{array}{c}\text { GDP } \\
\text { (in Rupees) }\end{array}$ \\
\hline Mean & 193,803 & $2,099,638$ & $1,715,661$ & $18,982,274$ \\
Minimum & 5,162 & 62,205 & $1,008,092$ & $10,637,772$ \\
Maximum & 847,236 & $9,239,786$ & $2,589,978$ & $27,383,722$ \\
Std. Dev. & 217,668 & $2,406,762$ & 550,728 & $5,865,077$ \\
\hline Source: Author's estimation & & &
\end{tabular}

\section{Stationary Analysis}

An initial step for assessing the relationship between time series variables is to check the integration property of all the data series. It is because if the data series contains a trend, it will overestimate the regression results. Therefore, the order of the integration of the variables are initially assessed by Augmented Dickey fuller (ADF) test. The results are presented in table 2; it shows that tax revenue and GDP both are non-stationary at level and stationary at first difference. Hence, it confirms that both the variables are integrated at order one I (1), suggesting the expected long-term relationship between variables.

Table 2

\begin{tabular}{lcccc}
\multicolumn{4}{l}{ Stationary Analysis } \\
\hline Variables & \multicolumn{2}{c}{ ADF Test Statistics } \\
\hline \multicolumn{4}{c}{ I(0) } & \multicolumn{2}{c}{ I(I) } \\
\hline TR & C & C\&T & C & C\&T \\
GDP & -2.545 & -3.874 & -5.031 & -5.286 \\
\hline \multicolumn{2}{l}{ Source: Author's estimation } & &
\end{tabular}

\section{Cointegration Analysis}

The stationary property of the data series indicating the expected presence of cointegration in the model. For that purpose, we used Johansen and Juselius cointegration test to check the long run relationship between tax revenue and gross domestic product. The results of 
Johansen and Juselius cointegration is presented in table 3. By trace statistics, the result suggests that tax revenue and gross domestic product are cointegrated with each other. Similarly, the statistics of max. Eigen value also confirms that both the variables are highly cointegrated.

Table 3

Johansen and Juselius Cointegration Analysis

\begin{tabular}{lcccc}
\hline $\begin{array}{l}\text { Hypothesized } \\
\text { No. of CE(s) }\end{array}$ & $\begin{array}{c}\text { Trace } \\
\text { Statistics }\end{array}$ & $\begin{array}{c}\text { 5\% Critical } \\
\text { Value }\end{array}$ & $\begin{array}{c}\text { Max. Eigen } \\
\text { Value Statistics }\end{array}$ & $\begin{array}{c}\text { 5\% Critical } \\
\text { Value }\end{array}$ \\
\hline None ${ }^{*}$ & 35.158 & 12.321 & 25.874 & 11.225 \\
At most 1 & 9.284 & 4.13 & 9.284 & 4.13 \\
\hline Source: Author's estimation & & &
\end{tabular}

\section{Regression Analysis}

To investigate the effect of SARA on tax revenue and tax buoyancy, we estimate a model using regression analysis. The results are illustrated in table 4; it shows that all the explanatory variables are sufficient to explain their effects on the response variable because the adjusted $\mathrm{R}$ square is $99 \%$. Furthermore, the individual effect of variables suggests that gross domestic product has a positive and significant impact on the tax revenue of Pakistan. Whereas, the effect of semi-autonomous revenue agency (SARA) has a positive but insignificant impact on the tax revenue of Pakistan. However, the coefficient of interaction variable of real national income and pre and post SARA period (DUM*lnGDP) has a negative and insignificant impact on the tax revenue, indicating a downward shift of tax buoyancy concerning the change in real gross domestic product and tax policy decisions. By adding the coefficient of lnGDP with the slope dummy variable, it gives the magnitude of tax buoyancy of post-SARA period. The coefficient of tax buoyancy in post SARA period is $0.948[0.997+(-0.049)]$, indicates that every 1 per cent change in real GDP bring 0.948 per cent change in tax revenue by the tax system of Pakistan.

The results of regression analysis show that increase in the gross domestic product will increase the tax revenue of Pakistan. It is likely because an increase in the national income will definitely raise the consumption and investment of an individual and hence increases the revenue collected from taxes. Also, the semi-autonomous revenue agency (SARA) of Pakistan, i.e., the federal board of revenue (FBR) has a positive but insignificant impact on the tax revenue. The effect of tax reforms become insignificant might be due to the improper execution, lack of management, prevalence of civil management culture, nonprofessionals, etc. This finding is consistent with the findings of (Khan, 1973; Devas, Delay, \& Hubbard, 2001; Bird, Martinez-Vazquez, \& Torgler, 2008). They also argued that bureaucratic culture, particularly in developing nations, stop SARA to execute these tax reforms properly. Also, the curse of corruption and political interferences are one of the external factors that direct or indirect influence the effective implementation of tax reforms in the country. In Pakistan, unfortunately, the state is facing all these problems of weak governance, political interference and corruption. Though the positive relation exists between SARA reforms and tax revenue in Pakistan, due to the ineffective execution of SARA, the effect of reforms become insignificant. However, on the other hand, the effect of tax buoyancy on the tax revenue is also found negative and insignificant during pre and 
post reform period. By this finding, we can comprehend that federal board of revenue is unable to increase tax revenue in the post reform period. This finding is also similar to the findings of Ndedzu et al. (2013); Okech and Mburu (2011); Kargbo and Egwaikhide (2012) etc.

Table 4

Regression Analysis

\begin{tabular}{lccc}
\hline \multicolumn{4}{l}{ The dependent variable is Tax Revenue (TR) } \\
\hline Variables & Coefficients & T-stats & Prob-value \\
\hline lnGDP & 0.997 & 50.652 & 0.000 \\
DUM & 0.811 & 0.505 & 0.616 \\
D2 & -0.049 & -0.498 & 0.621 \\
Constant & -2.327 & -8.322 & 0.000 \\
\hline Adj. R-square: & 0.999, D.W: & 2.15, F-stats: & $1101107(0.000)$ \\
\hline \multicolumn{4}{l}{ Source: Author's estimation }
\end{tabular}

\section{Causality Analysis}

To check the bivariate causal relationship between tax revenue and gross domestic product, we use granger causality test. Table 5 presents the results of causality test. The null hypothesis assumes the no causal against the causal relationship between the variables. It is found that tax revenue does not cause the gross domestic product of Pakistan. However, the gross domestic product causes the tax revenue in Pakistan. Thus, we can conclude that there is unidirectional causal relationship between tax revenue and gross domestic product.

\begin{tabular}{lcc}
$\begin{array}{l}\text { Table } 5 \\
\text { Granger Causality Test }\end{array}$ & & \\
\hline Null Hypothesis: & F-Statistic & Prob. \\
\hline LTR does not Granger Cause LGDP & 1.696 & 0.200 \\
LGDP does not Granger Cause LTR & 15.812 & 0.000 \\
\hline Source: Author's estimation & &
\end{tabular}

\section{Conclusion and Policy Implications}

The current study aimed to investigate the effects of tax reforms on the tax revenue and tax buoyancy of Pakistan. An annual time series data for the period of 1972 to 2015 was used, which was further categorized in to pre-reform period and post reform period. The pre-reform period covers the years from 1972-2006, whereas, the establishment of a federal board of revenue (FBR) in 2007 and the latter years (2007-2015) covers the post reform period. We used dummy variables to measure the effect of SARA reforms and tax buoyancy. Prior estimating the model, we first ensured the stationarity of the data series. By using augmented dickey fuller (ADF) test, we confirmed that data series of all the variables have no trend. Also, Johansen and Juselius cointegration test confirmed the long run relationship between tax revenue, tax reforms, and tax buoyancy.

Furthermore, the model was estimated by using regression analysis. Results revealed that gross domestic product has a positive and significant impact on the tax revenue of Pakistan. However, results also confirmed that the establishment of a federal board 
of revenue (FBR) has a positive but insignificant impact on the tax collection system of Pakistan. It might be due to the lack of efficient management approaches, weak governance system, more political involvement and most importantly corruption. These factors nullify the effect of SARA reforms on the productivity of tax revenue. Whereas, the interaction of gross domestic product and SARA reforms indicated that changes in real income controlled by reforms have a negative and insignificant impact on the tax revenue. It is mainly because Pakistan is stated with high involvement of politics in organizations. Despite facilitating and encouraging the tax payers, the system distorts the function and create hurdles for tax payers, which further discouraged tax payers to pay taxes and thus reduces revenue.

The above empirical finding of this study can draw several insights for the policy makers. In the first place, the government of Pakistan needs to rebound the system of tax revenue authority by improving the performance of different departments. A federal board of revenue should possess all the characteristics of independent administrative authority. FBR should take some measure to ensure the tax equity by including the income tax of agricultural sector. Moreover, some incentive policies should be introduced for the tax payers who pay tax properly and encourage tax culture. Lastly but importantly, the state should prevent FBR to behave like a conventional autonomous body.

\section{Recommendations for Future Researches}

Even though this study has fulfilled its objective but has few limitations. The one of the limitations is the selection of variable. We have not used any control variable that affect the performance of tax revenue. Therefore, future researchers can add controlled variables in the existing model that affect tax revenue. Moreover, studies can use tax elasticities to measure the responsive change in real income and tax revenue. Within the context of Pakistan, future studies can also assess the individual effect of direct and indirect taxes. Moreover, from the econometric perspective, some advance statistical approaches can also be used to further explore the richer effect of tax reforms on the tax revenue and buoyancy. Finally, the same model can further be used for the regional analysis. 


\section{References}

Ahmed, Q. M., \& Muhammad, S. D. (2010). Determinant of tax buoyancy: Empirical evidence from developing countries. European Journal of Social Sciences, 13(3), 408-414.

Ariyo, A. (1997). Productivity of the Nigerian Tax System. Research Paper 67 presented in African Economic Research Consortium, Nairobi.

Bekoe, W., Danquah, M., \& Senahey, S. K. (2016). Tax reforms and revenue mobilization in ghana. Journal of Economic Studies, 43(4), 522-534.

Bird, R. M., Martinez-Vazquez, J., \& Torgler, B. (2008). Tax effort in developing countries and high income countries: The impact of corruption, voice and accountability. Economic Analysis and Policy, 38(1), 55-71.

Devas, N., Delay, S., \& Hubbard, M. (2001). Revenue authorities: Are they the right vehicle for improved tax administration? Public Administration and Development, $21(3), 211-222$.

Di John, J. (2011). Taxation, developmental state capacity and poverty reduction. International Journal of Social Welfare, 20(3), 270-279.

Eubank, N. (2012). Taxation, political accountability and foreign aid: Lessons from somaliland. Journal of Development Studies, 48(4), 465-480.

Gillani, S. F. (1986). Elasticity and buoyancy of federal taxes in Pakistan. The Pakistan Development Review, 25(2), 163-174.

Kargbo, B. I. B., \& Egwaikhide, F. O. (2012). Tax elasticity in sierra leone: A time series approach. International Journal of Economics and Financial Issues, 2(4), 432-447.

Khan, M. Z. (1973). The responsiveness of tax yield to increases in national income. The Pakistan Development Review, 12(4), 416-432.

Kidd, M., \& Crandall, W. J. (2006). Revenue authorities: Issues and problems in evaluating their success (No. 6-240). International Monetary Fund.

Levi, M., \& Sacks, A. (2009). Legitimating beliefs: Sources and indicators. Regulation \& Governance, 3(4), 311-333.

Muriithi, M. K., \& Moyi, E. D. (2003). Tax reforms and revenue mobilization in Kenya. Research paper 131 presented in African Economic Research Consortium, Nairobi.

Musa, O. D., Bulus, A., Nwokolo, C. C., \& Yuni, D. N. (2016). Tax buoyancy and elasticity in Nigeria: The case of aggregate tax. International Journal of Development and Economic Sustainability, 4(4), 20-31.

Ndedzu, D., Macheka, A., Ithiel, M. M., \& Zivengwa, T. (2013). Revenue productivity of Zimbabwe's tax system. Asian Journal of Social Sciences 63 Humanities, 2(4), $144-156$.

Okech, T. C., \& Mburu, P. G. (2011). Analysis of responsiveness of tax revenue to changes in national income in Kenya between 1986-2009. International Journal of Business and Social Science, 2(21), 275-287.

Omondi, O. V., Wawire, N. H., Manyasa, E. O., \& Thuku, G. K. (2014). Effects of tax reforms on buoyancy and elasticity of the tax system in Kenya: 1963-2010. International Journal of Economics and Finance, 6(10), 97-111. 
Osoro, N. E. (1993). Revenue productivity implications of tax reform in Tanzania. Research Paper No. 20 presented in African Economic Research Consortium, Nairobi. Centre for the Study of African Economies, University of Oxford, Oxford, GB.

Prest, A. R. (1962). The sensitivity of the yield of personal income tax in the United Kingdom. The Economic Journal, 72(287), 576-596.

Singer, N. M. (1968). The use of dummy variables in estimating the income-elasticity of state income-tax revenues. National Tax Journal, 21 (2), 200-204.

Taliercio Jr, R. R. (2004). Administrative reform as credible commitment: The impact of autonomy on revenue authority performance in Latin America. World Development, 32(2), 213-232.

Talvi, E., \& Vegh, C. A. (2005). Tax base variability and procyclical fiscal policy in developing countries. Journal of Development Economics, 78(1), 156-190.

Tax Administration in OECD and Selected Non-OECD Countries. (2011). Retrieved September 12, 2017, from Centre for Tax Policy and Administration website: https://www.oecd.org/tax/administration/CIS-2010.pdf.

Upender, M., et al. (2008). Degree of tax buoyancy in India: An empirical study. International Journal of Applied Econometrics and Quantitative Studies, 5(2), 59-70.

Von Haldenwang, C., Von Schiller, A., \& Garcia, M. (2014). Tax collection in developing countries- New evidence on semi-autonomous revenue agencies (SARAs). Journal of Development Studies, 50(4), 541-555. 